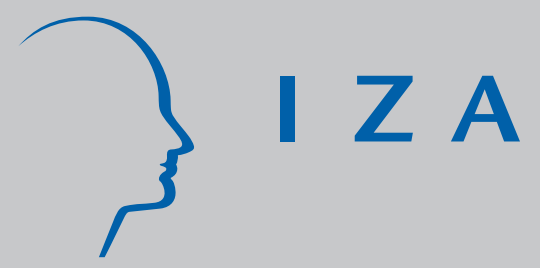

IZA DP No. 1280

Why Do Self-Employed Immigrants in Denmark and Sweden Have Such Low Incomes?

PernillaAndersson

Eskil Wadensjö

August 2004 


\title{
Why Do Self-Employed Immigrants in Denmark and Sweden Have Such Low Incomes?
}

\author{
Pernilla Andersson \\ Swedish Institute for Social Research, \\ Stockholm University \\ Eskil Wadensjö \\ Swedish Institute for Social Research, \\ Stockholm University and IZA Bonn
}

\section{Discussion Paper No. 1280 August 2004}

\author{
IZA \\ P.O. Box 7240 \\ 53072 Bonn \\ Germany \\ Phone: +49-228-3894-0 \\ Fax: +49-228-3894-180 \\ Email: iza@iza.org
}

\begin{abstract}
Any opinions expressed here are those of the author(s) and not those of the institute. Research disseminated by IZA may include views on policy, but the institute itself takes no institutional policy positions.

The Institute for the Study of Labor (IZA) in Bonn is a local and virtual international research center and a place of communication between science, politics and business. IZA is an independent nonprofit company supported by Deutsche Post World Net. The center is associated with the University of Bonn and offers a stimulating research environment through its research networks, research support, and visitors and doctoral programs. IZA engages in (i) original and internationally competitive research in all fields of labor economics, (ii) development of policy concepts, and (iii) dissemination of research results and concepts to the interested public.
\end{abstract}

IZA Discussion Papers often represent preliminary work and are circulated to encourage discussion. Citation of such a paper should account for its provisional character. A revised version may be available directly from the author. 


\title{
ABSTRACT
}

\section{Why Do Self-Employed Immigrants in Denmark and Sweden Have Such Low Incomes?*}

\begin{abstract}
When studying income differences and income distribution, the self-employed are often excluded from the population studied. There are several good reasons for this, for example that incomes from self-employment are not reported to the same extent as incomes from being an employee. On the other hand it is a problem to exclude the self-employed when studying income differences if the group is large, if the share that is self-employed differs between groups and if there is a difference in the average income from self-employment compared to the average wage income. This is the case when we study incomes for immigrants in Western Europe. The immigrants are overrepresented among the selfemployed, self-employed immigrants are in other sectors than self-employed natives, and the incomes from self-employment differ from the incomes of the wage earners. In this paper we look at the incomes for the self-employed in Denmark and Sweden. To minimize the problems with unreported income we will mainly compare the annual incomes of the selfemployed immigrants and their native counterparts. The measurement error should only create a bias in the estimate of the income difference between the groups if there is a systematic difference in how they report their incomes. Using two cross-sections, one for each country, we find large income differences between natives and immigrants in both countries. Regression estimates show that most characteristics have the same influence in the two countries but also some interesting differences. Using quantile regressions we find that the difference in annual incomes differs depending on where in the income distribution we look. We find that the difference is smaller higher up in the distribution.
\end{abstract}

JEL Classification: J15, J23, J61

Keywords: immigrant workers, self-employment, quantile regressions, income differences

Corresponding author:

Eskil Wadensjö

Swedish Institute for Social Research

Stockholm University

SE 10691 Stockholm

Sweden

Email: Eskil.Wadensjo@sofi.su.se

\footnotetext{
* We would like to thank seminar participants at the ESPE conference in Bergen in June 2004 for helpful comments. Financial support from IFAU and the Rockwool Foundation is gratefully acknowledged.
} 


\section{Introduction}

The self-employed have often been excluded in the research on income differences between natives and immigrants. The reason for this is primarily that there is a problem in interpreting their incomes. One often assumes that there is a lower correlation between their incomes and their living standards and consumption possibilities than is the case for employees (Bradbury 1996).

We believe that a study of income differences for self-employed is of interest for several reasons. In general the share of self-employed, excluding farmers, has increased in many countries including Denmark and Sweden. This form of employment is an important part of the economies of the countries. The birth and expansion of new businesses and workplaces strongly influence the growth of the economies and the development of their employment. Self-employment can also be a way for those having difficulties in getting a regular job to become economically self-reliant and avoid being dependent on benefits. These smaller firms and businesses can also provide employment possibilities for other people besides the selfemployed individual, such as family members, relatives and friends. It is also known that immigrants, particularly those from non-Western countries, are overrepresented among the self-employed compared to all employed. This is the case both in Denmark and Sweden. It has become more and more important to understand the incomes and living standards for the self-employed. In this paper we restrict the analysis to incomes, but later on we intend to include other measures on living standards besides the income reported to the tax authorities.

In the present study we ask whether self-employed immigrants in Denmark and Sweden have lower annual incomes than their native counterparts, and whether the difference is of the same magnitude in the two countries. ${ }^{1}$ To explain possible differences between immigrants and natives we discuss for example how differences in traditions, differences in reservation wages and different forms of discrimination can contribute. Regarding the differences between the countries, explanations can possibly be found in differences in the institutional set-up. For example, do the countries have different forms of support for the start up of a new business, different tax rules, or different business structures and traditions? Or are the immigrants who come to Denmark and Sweden different in ways that influence their propensity to start and successfully manage a business of their own?

In general when one studies income differences between groups one wants to explain possible differences. What can explain income differences between men and women and between

\footnotetext{
${ }^{1}$ In two earlier studies we have dealt with other aspect of self-employment in Denmark and Sweden using the same data sets. See Andersson and Wadensjö (2004 and 2004a).
} 
natives and immigrants? If the difference still stands after controlling for a number of explanatory variables which are likely to be driving forces behind the difference, one is often left with the explanation that there is some form of discrimination. However, it is difficult to empirically show that there is discrimination. Rather, this is a possible explanation when we cannot explain income differences between otherwise similar individuals. A motive for studies like this is to distinguish between reasons for differences that can be affected by policy and reasons that can not. If for example self-employed immigrants are found to have lower annual incomes than self-employed natives due to that they have been in business fewer years than natives then policymakers cannot do much about it. But if one rather finds that observable characteristics that differ between the groups cannot fully explain the immigrantnative income gap and one comes to the conclusion that it appears to be some form of discrimination, then policy changes can perhaps have an impact.

The motivation behind this study is also that we want to identify and explain possible income differences between self-employed natives and immigrants. Since we use a cross section for two countries there are several explanations we cannot explicitly test for but to do this is definitely a challenge for future research.

In the empirical analysis we start by estimating ordinary least square regressions with $\log ($ income $)$ as the dependent variable to get information on which factors influence income from self-employment and if the factors and the size and sign of the factors are the same in the two countries. We continue by estimating quantile regressions for different percentiles of the distribution. The reason for doing so is that there is reason to believe that there are two types of selection into self-employment, positive and negative. Some people choose to become self-employed since this is actually what they prefer as opposed to being a wage earner, and this is what they are good at. On the other hand, self-employment has often been seen as an escape from unemployment. By using the quantile regression technique we can look at the immigrants-native income gap in different percentiles and thereby make use of the possible selection into self-employment in explaining the gap.

The paper is organised as follows. In section two we discuss how possible differences between the groups can be explained. In section three we present our data and include an extensive discussion of the problems in analyzing incomes for self-employed. Our results are presented in section four, and in section five we discuss how the results are related to the theoretical analysis. Finally, section six concludes and summarizes. 


\section{How can one explain within and between country differences in the incomes for self-employed?}

Do self-employed immigrants have the same incomes as self-employed natives? It is reasonable to expect that factors that influence the incomes of self-employed natives as age, gender, family status and education also influence the incomes of self-employed immigrants. Of interest here are not so much the similarities as the existence of any dissimilarity. Are there reasons to expect that immigrant and native self-employed with the same characteristics are receiving different incomes? There may be several different explanations for such differences. The decisions to become self-employed are made under different circumstances for the two groups and when establishing themselves as self-employed they may be treated differently for example by consumers, authorities and financial institutions.

Some immigrants come from countries with more of self-employment than in Denmark and Sweden or from social groups with that type of tradition and also with competency and the kind of networks that support the establishment of self-employment. This factor, the cultural factor, goes in the direction of higher propensity among (some groups of) immigrants than natives to establish a business of their own. This may also imply higher skills in handling the business and by that higher income. It should be stressed that not all immigrants come from countries and groups with a tradition of and high skills in managing a business of their own.

The propensity to establish a business of their own may also be influenced by the labour market situation. Those with a weak position in the labour market may become self-employed not due to that it is the preferred form of employment, but due to a lack of possibilities to get a job. And immigrants from non-Western countries generally have a weaker position in the labour market than natives. It implies that the reservation (expected) income from selfemployment may be lower among immigrants than among natives. That would lead to a hypothesis that the immigrants are over-represented among the self-employed with low incomes.

The argument is that differences in reservation wage between immigrants and natives can contribute to explain the income gap between self-employed immigrants and natives. Immigrants from less developed countries are often assumed to have a lower reservation wage than natives. One reason for this is that immigrants from these regions have more difficulties in getting a job. For Sweden, for example, one finds relatively small differences in hourly wage between natives and immigrants while there are large differences in employment level. ${ }^{2}$

\footnotetext{
${ }^{2}$ See for example Vilhelmsson (2002).
} 
This situation has often been attributed to the centralised wage-bargaining system in Sweden and that it is impossible to underbid the current wage rate. The situation is different for selfemployed. It is possible that immigrants, due to having a lower reservation wage, are prepared to start a business more often than natives. This difference in "start-up" behaviour can be translated into lower incomes for self-employed immigrants compared to their native counterparts. This argument seems to be a reasonable explanation for the immigrant-native income gap for immigrants who started their firm after spending relatively few years in the host country. But as immigrants assimilate to the labour market situation it is likely that their reservation wages will approach those of natives.

Different types of self-employment require different forms of education and different levels of financial resources. Self-employed immigrants may have easier access to some sectors of the economy, sectors not requiring a special exam or license, or requiring access to a large capital for starting the business. This is also a process that may explain that self-employed immigrants are over-represented among self-employed with low incomes. By increasing competition such a crowding into a few sectors may lead to low incomes.

Are there any other factors besides selection into some occupations that may explain differences in income from self-employment? Some forms of discrimination could be an explanation. Self-employed immigrants could be discriminated by customers preferring native-owned businesses. There could also be discrimination from financial institutions being less favourably inclined to grant loans to businesses owned by immigrants. There could also be discrimination from the authorities regarding the treatment of self-employed immigrants compared to native ones, for example regarding giving the right to establish a retailing business in a new housing area. Discrimination, if existing, could contribute to explain that self-employed immigrants have lower incomes than self-employed natives.

Both in Denmark and Sweden unemployed individuals, or people who face a threat of unemployment, are eligible to receive financial support to start a business. It is well known that unemployment rates are higher among immigrants than among natives, so it is reasonable to assume that immigrants more often are placed in such programs. The support generally means that the participant continues to get unemployment benefits for a period even if a person is working as self-employed. This transfer income means that a self-employed person may have an income even if the income from self-employment is low (or even none). When we are comparing the incomes we are not including the transfer incomes. Since immigrants (due to higher unemployment) are overrepresented in those programs, it probably lowers the 
ratio between the incomes of self-employed and the incomes of wage earners in the two countries.

We are studying the incomes of self-employed natives and immigrants in two countries, Denmark and Sweden. If we get similar results we have some support for the hypothesis that the same factors are important in both countries. Before continuing we ask ourselves if there is any reason to expect that there are differences in the factors determining the incomes of self-employed in the two countries and the relative incomes of native and immigrant selfemployed. The two countries are neighbours and similar in many respects but there are also differences which may be important in this case.

The distribution of incomes on different family members may differ between the two countries. In many small businesses only one person is the formal business owner, the selfemployed in our statistics, but in practice other members of the family work to a lower or higher extent in the business. In such cases it is not self-evident how the incomes from the business should be distributed on different family members when reporting to the tax authorities and by that also to other authorities. The distribution could be influenced by rules regarding taxes and social transfers. The progressive tax income tax system in Denmark and Sweden gives incentives to distribute the income from the business on several family members. On the other hand, there may be factors going in the other direction. An income from self-employment, even if it is small, may make it impossible to get unemployment benefits if they have no other work. In Denmark this could also influence social welfare payments. Social welfare in Denmark is granted for each individual independent of the incomes of other members of the household. In Sweden on the other hand welfare payments are dependent on the incomes of the household not of the individual. This means that there are stronger incentives in Denmark than in Sweden for some households to concentrate the incomes from self-employment to one member of the household. This should lead us to expect that self-employed in Denmark have higher registered incomes than self-employed in Sweden. This effect should be the same for immigrants and natives if the labour market situation for other members of the household is the same in the two groups.

The discussion above gives us two hypotheses:

1. That self-employed immigrants have lower incomes than self-employed natives in both countries.

2. That the incomes of self-employment relative to the income of wage earners will be higher in Denmark than in Sweden. 


\section{Data}

The study is based on data from two different sources. We use the Danish Ministry of Economic Affairs' Law Model for individuals who live in Denmark. ${ }^{3}$ This database contains detailed information on 3.3 percent of the population living in Denmark in 1999 and after imposing restrictions on the sample we have a population of 72844 individuals. For Sweden we use data from the register-based labour market statistics (RAMS). ${ }^{4}$ We have information on all individuals living in Sweden in December 1999. To make the Swedish data comparable in size with the Danish, a 2.6 percent sample was taken from the RAMS database. After several restrictions are imposed, the Swedish sample contains 81388 individuals. About 3 per cent, or 2276 individuals are self-employed and 79112 are wage earners. In the Danish sample, about 3000 individuals, or 4 per cent, are self-employed. Throughout this study, selfemployed are defined as those who do not have any income from employment in a firm in addition to the incomes earned from self-employment. ${ }^{5}$

\subsection{Restriction of the data}

The study is based on register data provided on an annual basis. Since we do not have information on working hours, and the income variable we have used is the total annual income, we try to restrict the sample to only include individuals who have either income from self-employment or wages as their main income source during the year of study. We have chosen to exclude individuals who:

- $\quad$ are students

- $\quad$ are unemployed at the time for measurement

- have received unemployment insurance benefits at some point during the year

- have received transfers from the social security system that exceed the annual income (Sweden)

- have received social insurance benefits for sick-leave, pregnancy, and rehabilitation (Denmark).

- receive some form of income compensation for early retirement

- $\quad$ have done their military service during the year (Sweden)

- $\quad$ work in the agricultural sector.

\footnotetext{
${ }^{3}$ See Ministry of Economic Affairs (2000) for a presentation of the database.

${ }^{4}$ See Statistics Sweden (1999) for information about the data.

${ }^{5}$ Throughout the study only employed individuals between 18 and 64 years of age are included. Farmers are excluded from the analysis.
} 


\subsection{Problems in analysing the incomes of self-employed}

There are two main problems in analysing the incomes of the self-employed. The first difficulty is related to that the incomes are not comparable to those that wage-earners receive. An employee basically receives the same income independent of how well the firm is doing. The employer has an obligation to pay a wage that is in part related to the amount of work that has been done during a certain period of time. In principle, the more hours you work as employed the higher income you get. The situation is not the same for the self-employed. Their incomes are closely related to how well it is going for the firm. For self-employed, more hours put into the firm do not necessarily mean a higher income. This is perhaps especially the case when starting-up a business. However, as mentioned earlier, in this paper we focus on the immigrants/native income gap among self-employed. We are not primarily interested in comparing self-employed and wage earners, although we will refer to the immigrantsnative income gap among wage earners as a comparison.

The second concern related to the study of incomes of self-employed, is the possibility of a severe measurement error in the income reported to the tax agency, the variable that we use. Self-employed with the kind of firms that we study have different possibilities of dealing with the economy of their business. However, this causes a bias in our estimates of the immigrantsnative income gap only if there is a systematic difference in how the two groups report their incomes. We do not have any indication for such a difference. For this reason we believe that the possible measurement errors do not cause any severe problem.

\subsection{Empirical methods - quantile regressions}

In this section we will give a brief description of the methods used, quantile regression. The advantage of using quantile regressions is that we can estimate the marginal effects in different regions of the distribution and not only at the mean values as with OLS. Since we have reason to believe that the income differences vary over the distribution, this approach seems to be the appropriate one. When estimating the income gap in an OLS regression, the underlying assumption is that the covariates affect natives and immigrants in the same way.

The quantile regression technique is a form of median regression where the sum of the absolute residuals is minimized. The objective of such a regression is to estimate the median of the dependent variable conditional on the covariates. In a more generalized version one is not restricted to only calculate the median value but can also calculate the value of the dependent variable at different percentiles in the distribution. We use a method where the 
equations for different percentiles are calculated simultaneously. One advantage of doing this is that we can test whether the estimated coefficients for a certain independent variable are significantly different from each other at different parts of the distribution. Another advantage of using this estimation technique is that bootstrapping is used to calculate the variancecovariance matrix. A formal explanation of how the quantiles are estimated can be seen in the manual for the STATA. The quantile that we want to estimate is called $\mathrm{q}$ and the residual for each observation can be written as:

$$
r_{i}=y_{i}-\sum_{j} \beta_{j} x_{i j}
$$

Let us then define a multiplier for each individual

$h_{i}=2 q$ if $r_{i}>0$ and $h_{i}=2(1-q)$ otherwise

We want to minimize $\sum_{i}\left|r_{i}\right| h_{i}$ with respect to $\beta_{j}$

To estimate the quantiles the residuals are weighted and the weight given to each individual residual depends on whether it is negative or positive. Estimating the $75^{\text {th }}$ percentile, i.e. for $\mathrm{q}$ $=0.75$, positive residuals have the weight 1.50 and negative residuals are weighted with 0.50 .

The method described above estimates a bootstrapped version of the variance-covariance matrix. Bootstrapped standard errors are better than those calculated analytically when estimating quantile regressions. The reason for this is that the standard errors are assumed to be heteroscedastic. This means that the variance of the residual component in the regression is not constant over observations and one can no longer assume that the estimated standard errors converge in their probability limit to the real standard error. This problem can then be dealt with by bootstrapping which is a resampling method. To calculate the variancecovariance matrix $m$ samples are drawn with replacement from the original data, where $m$ is a number to be chosen by the researcher. For each sample the mean value is calculated and we get a data set of $m$ estimated means. The sampling distribution of the population mean is then approximated with the distribution of the estimated means. ${ }^{6}$

\footnotetext{
${ }^{6}$ For thorough presentations of quantile regressions and bootstrapping, see Brownstone \& Valetta (2001), Mooney \& Duval (1993) and Wooldridge (2002),
} 


\section{Results}

We will start the presentation of the results by describing the raw income differences. In the next step we present the averages for the covariates included in the regressions. Thirdly, Kernel density estimations for the income distributions of the different groups are presented for both Denmark and Sweden. Fourthly, the results from OLS-regressions with log annual incomes in 1999 are presented. Fifthly, the results of the quantile regressions are presented for different specifications of the model. Only the coefficients for immigrant status are given.

Table 1. Mean income ratios for different groups in Denmark and Sweden calculated for total annual income

\begin{tabular}{lcc}
\hline & DENMARK & SWEDEN \\
\hline \hline Self-employed: & & \\
\hline $\begin{array}{l}\text { Western immigrants/Natives } \\
\text { Self-employed: }\end{array}$ & 0.73 & 0.92 \\
$\begin{array}{l}\text { Western immigrants (long)/Natives } \\
\text { Self-employed: }\end{array}$ & 0.73 & 0.93 \\
$\begin{array}{l}\text { Western immigrants (short)/Natives } \\
\text { Self-employed: }\end{array}$ & 0.72 & 0.82 \\
$\begin{array}{l}\text { Non-Western immigrants/Natives } \\
\text { Self-employed: }\end{array}$ & 0.44 & 0.59 \\
$\begin{array}{l}\text { Non-Western immigrants (long)/Natives } \\
\text { Self-employed: }\end{array}$ & 0.46 & 0.60 \\
$\begin{array}{l}\text { Non-Western immigrants (short)/Natives } \\
\text { Wage-earners: }\end{array}$ & 0.23 & 0.37 \\
$\begin{array}{l}\text { Western immigrant/Natives } \\
\text { Wage-earners }\end{array}$ & 0.99 & 1.02 \\
$\begin{array}{l}\text { Non-Western immigrant/Natives } \\
\text { Natives: }\end{array}$ & 0.72 & 0.82 \\
$\begin{array}{l}\text { Self-employed/Wage-earners } \\
\text { Western immigrants: }\end{array}$ & 1.54 & 0.61 \\
$\begin{array}{l}\text { Self-employed/Wage-earners } \\
\text { Non-Western immigrants: }\end{array}$ & 1.13 & 0.55 \\
$\begin{array}{l}\text { Self-employed/Wage-earners } \\
\text { Notes. Natives are defined as those who were born in the host country and whose } \\
\text { parents also were born in the host country; long = longer residency; short }= \\
\text { shorter residency. }\end{array}$ & & \\
\end{tabular}

In Table 1 mean income ratios are given for various groups. Only individuals who have been employed, either as a wage-earner or as self-employed, during the main part of the year are included. A description of how the groups are defined is given in Section 3 on data. The mean incomes for some groups are based on only a few observations and the results for those 
groups should be interpreted with great care. ${ }^{7}$ We will focus on the non-Western immigrants who have lived in the host country for five years or more. There are 133 and 264 observations in this group for Denmark and Sweden, respectively. If comparing wage-earners, we find that in both Denmark and Sweden Western immigrants on average have slightly higher, or almost the same, incomes as natives, and non-Western immigrants have lower incomes than natives. For the self-employed, both Western and non-Western immigrants have lower incomes than natives in both countries. Regarding the differences between countries, the most notable is that the ratio between the incomes for self-employed and those of wage earners is much higher in Denmark than in Sweden for all three groups. For example, in Denmark selfemployed natives have 54 per cent higher annual income on average than the wage earners, and in Sweden self-employed natives have 39 per cent lower income than the native wage earners. The corresponding figures for Western immigrants are 13 per cent higher in Denmark compared to 45 per cent lower in Sweden, and for non-Western immigrants 7 per cent lower in Denmark and 56 per cent lower in Sweden.

However, the ratios in the top rows of Table 1 are the ones we are most interested in; the immigrants/native income gap among self-employed. All ratios are smaller than one and they are lower for non-Western immigrants than for Western immigrants.

\footnotetext{
${ }^{7}$ In the group of self-employed immigrants that have lived in the host country for less than five years there are only 10 and 15 observations for Denmark of Western and non-Western immigrants, respectively. The corresponding numbers for Sweden are 6 and 11.
} 
Table 2. Descriptive statistics for covariates for self-employed in 1999

\begin{tabular}{|c|c|c|}
\hline & Denmark & Sweden \\
\hline Age & 45.9 years & 45.4 years \\
\hline Women & $30.1 \%$ & $30.3 \%$ \\
\hline One parent born in host country, one in Western country & $0.9 \%$ & $4.3 \%$ \\
\hline One parent born in host country, one in a non-Western country & $0.1 \%$ & $1.1 \%$ \\
\hline Both parents born in a Western country & $0.0 \%$ & $1.3 \%$ \\
\hline Both parents born in a non-Western country & $0.1 \%$ & $0.7 \%$ \\
\hline Born in a Western country; lived in host country five years or more & $0.8 \%$ & $5.5 \%$ \\
\hline Born in a Western country; lived in host country less than five years & $0.3 \%$ & $0.3 \%$ \\
\hline Born in a non-Western country; lived in host country five years or more & $4.4 \%$ & $11.6 \%$ \\
\hline Born in a non-Western country; lived in host country less than five years & $0.5 \%$ & $0.5 \%$ \\
\hline Primary school less than 9 years SE & & $14.5 \%$ \\
\hline Primary school 9(10) years SE & & $18.2 \%$ \\
\hline Upper secondary less than 2 years SE & & $33.4 \%$ \\
\hline Upper secondary 2 years or more SE & & $17.8 \%$ \\
\hline Higher education less than 3 years SE & & $9.5 \%$ \\
\hline Higher education 3 years or more SE & & $6.4 \%$ \\
\hline Post graduate education SE & & $0.2 \%$ \\
\hline Primary school $9(10)$ years DK & $27.7 \%$ & \\
\hline Upper secondary school DK & $4.5 \%$ & \\
\hline Vocational education DK & $50.2 \%$ & \\
\hline Short higher education DK & $4.2 \%$ & \\
\hline Medium-length higher education DK & $5.5 \%$ & \\
\hline Long higher education DK & $7.9 \%$ & \\
\hline Married & $80.0 \%$ & $57.7 \%$ \\
\hline Manufacturing & $8.5 \%$ & $9.1 \%$ \\
\hline Public utilities & $0.0 \%$ & $0.0 \%$ \\
\hline Construction & $14.8 \%$ & $16.1 \%$ \\
\hline Retailing & $27.3 \%$ & $21.0 \%$ \\
\hline Hotels and restaurants & $6.8 \%$ & $6.1 \%$ \\
\hline Transport, storage, communications & $8.6 \%$ & $12.1 \%$ \\
\hline Financial services & $0.2 \%$ & $0.0 \%$ \\
\hline Real estate and rental services & $17.9 \%$ & $17.5 \%$ \\
\hline Education & $0.9 \%$ & $0.9 \%$ \\
\hline Health and social services & $7.4 \%$ & $2.9 \%$ \\
\hline Public administration and other social and private services & $7.5 \%$ & $14.1 \%$ \\
\hline Household & $0.0 \%$ & $0.0 \%$ \\
\hline Number of employees SE & & 1.42 \\
\hline 0 employees DK & $51.3 \%$ & \\
\hline 1-9 employees DK & $46.7 \%$ & \\
\hline 10-49 employees DK & $1.7 \%$ & \\
\hline More than 50 employees DK & $0.3 \%$ & \\
\hline \multicolumn{3}{|l|}{ Average length of time spent in host country: } \\
\hline Born in a Western country & 11.5 years & 27.4 years \\
\hline Born in a non-Western country & 12.8 years & 15.1 years \\
\hline Born in a Western country; lived in host country five years or more & 14.5 years & 28.5 years \\
\hline Born in a Western country, lived in host country less than five years & 2.2 years & 3.2 years \\
\hline Born in a non-Western country, lived in host country five years or more & 13.9 years & 15.6 years \\
\hline Born in a non-Western country, lived in host country less than five years & 3.2 years & 2.7 years \\
\hline Number of observations & 3014 & 2276 \\
\hline
\end{tabular}


In Table 2, descriptive statistics are given for the controls included in the regressions. Later we will discuss which impact the length of stay in the host country can have on the incomes generated by self-employed immigrants. The average length of time different groups of immigrants have been in a country is to a large extent explained by the development of immigration over time. Those born in a Western country came to Sweden to a high extent in the 1960s and the beginning of the 1970s, a period characterised by labour immigration, while those born in a non-Western country on average came about ten years later in a period dominated by refugee immigration. In Denmark the pattern is different. The two groups of immigrants have on average been in Denmark for about the same length of time, between 11 and 13 years. Large scale labour migration to Denmark started later, in the late 1960s, and ended with the first oil crisis in 1973. Many of the labour migrants of that period came from non-Western countries. After that there has been labour immigration on a low level mainly from the other Nordic countries and other EU countries, i.e. from Western countries, and a much larger immigration of refugees from non-Western countries.

The difference in migration history can contribute to explain the differences we have found. To highlight the differences between Denmark and Sweden in this matter, Kernel density estimations are given for years spent in the host country for the different groups of immigrants. ${ }^{8}$ Immigrants from non-Western countries have spent almost the same time on average in Denmark and Sweden. This can be seen in Figure 2 where we can also see that the distributions are similar. This is not the case for immigrants from Western countries as can be seen in Figure 1. During the period when Sweden had a high share of labour immigration from Western countries such as Finland, Greece and Italy, very few people from those countries emigrated to Denmark.

\footnotetext{
${ }^{8}$ Kernel density estimators basically show the same thing as a histogram but in a more sophisticated way. There are two important differences between a histogram and the kernel density estimates. First, the intervals are allowed to overlap. Second, when a histogram only counts the number of observations in an interval, the kernel function in addition assigns a weight between 0 and 1 to each observation. The weight is based on the distance to the centre of the interval. Then the weighted values are summarized. For an additional description see the STATA manual.
} 
Figure 1. Kernel density estimates for years spent in host country. Self-employed immigrants from a Western country living in Denmark and Sweden

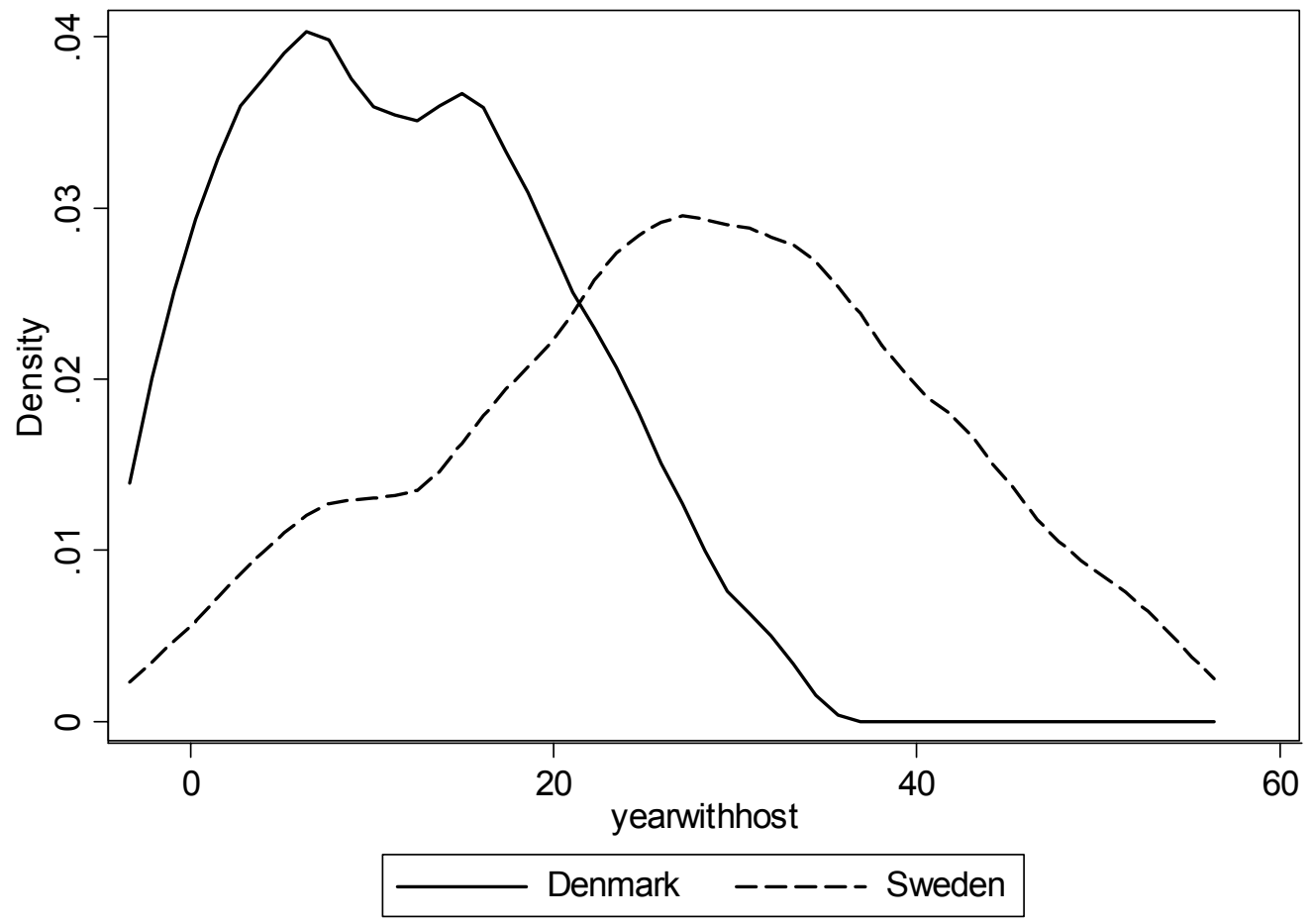

Figure 2. Kernel density estimates for years spent in host country. Self-employed immigrants from a non-Western country living in Denmark and Sweden

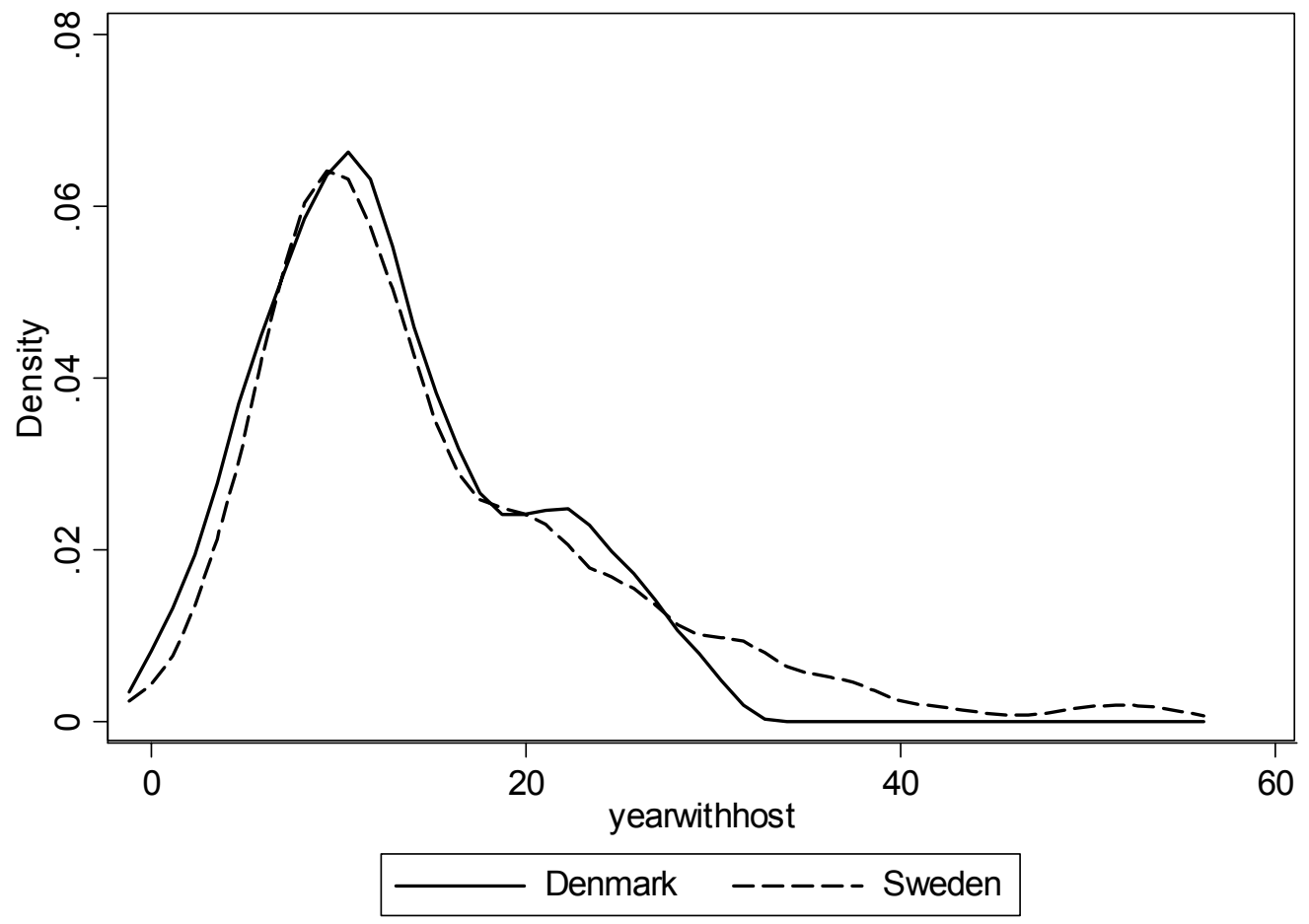


Kernel density estimates are also shown for the log income. ${ }^{9}$ This is an illustrative method to get an overview of how the income distribution for immigrants is compared to that for natives. The estimates are shown both for Denmark and Sweden. Note that the scale is not the same in Figures 3 and 4. The distribution is slightly more compressed in Sweden than in Denmark, but they are remarkably alike for immigrants and natives in Sweden. In both countries there is a small fraction with very low incomes, but the distributions coincide for immigrants and natives.

Figure 3. Kernel density estimates for self-employed in Denmark 1999

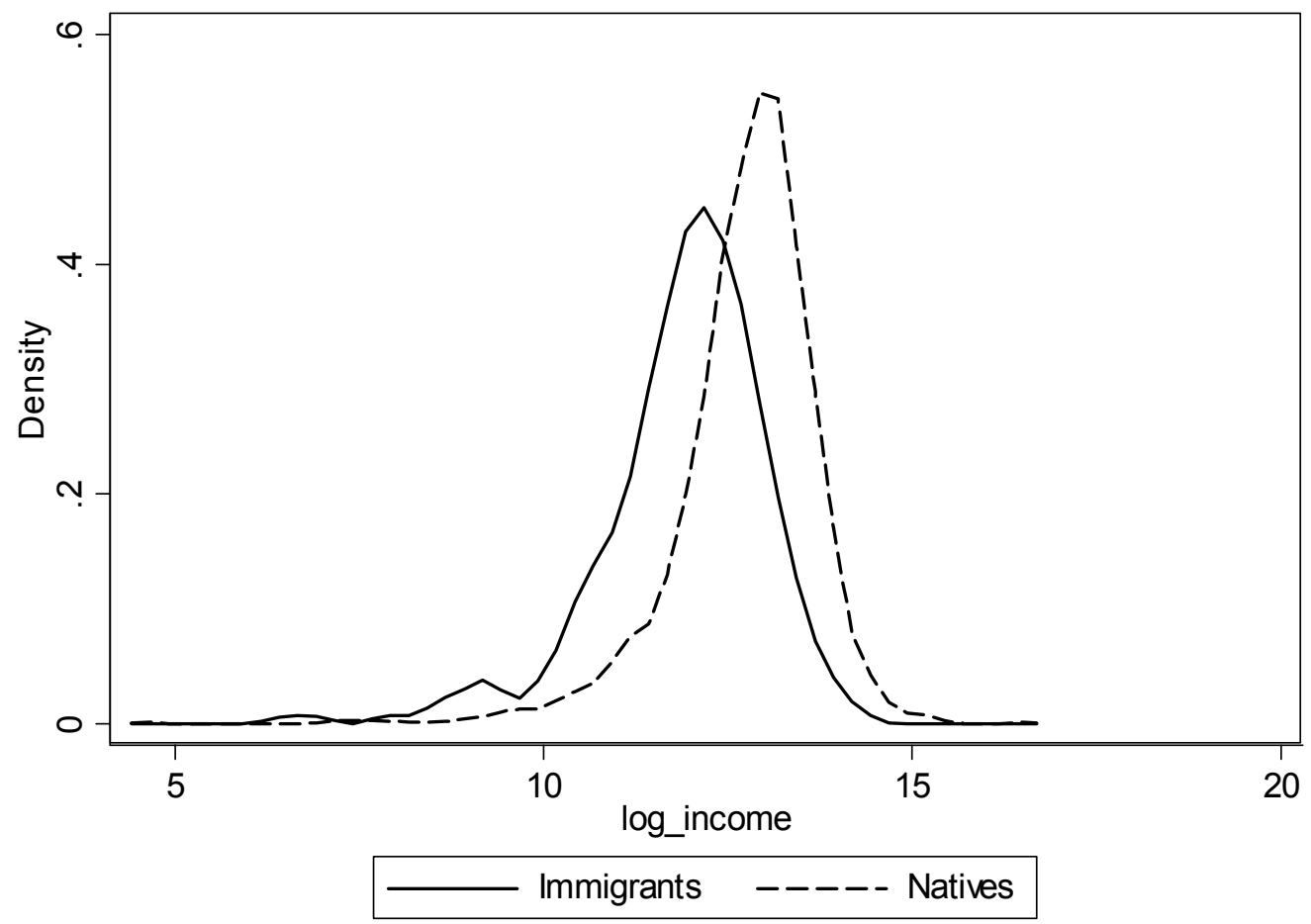

\footnotetext{
${ }^{9}$ The annual incomes are in SEK. The average exchange rate in 1999 between the Swedish and Danish currencies was $1.18 \mathrm{SEK}=1 \mathrm{DKK}$.
} 
Figure 4. Kernel density estimates for self-employed in Sweden 1999

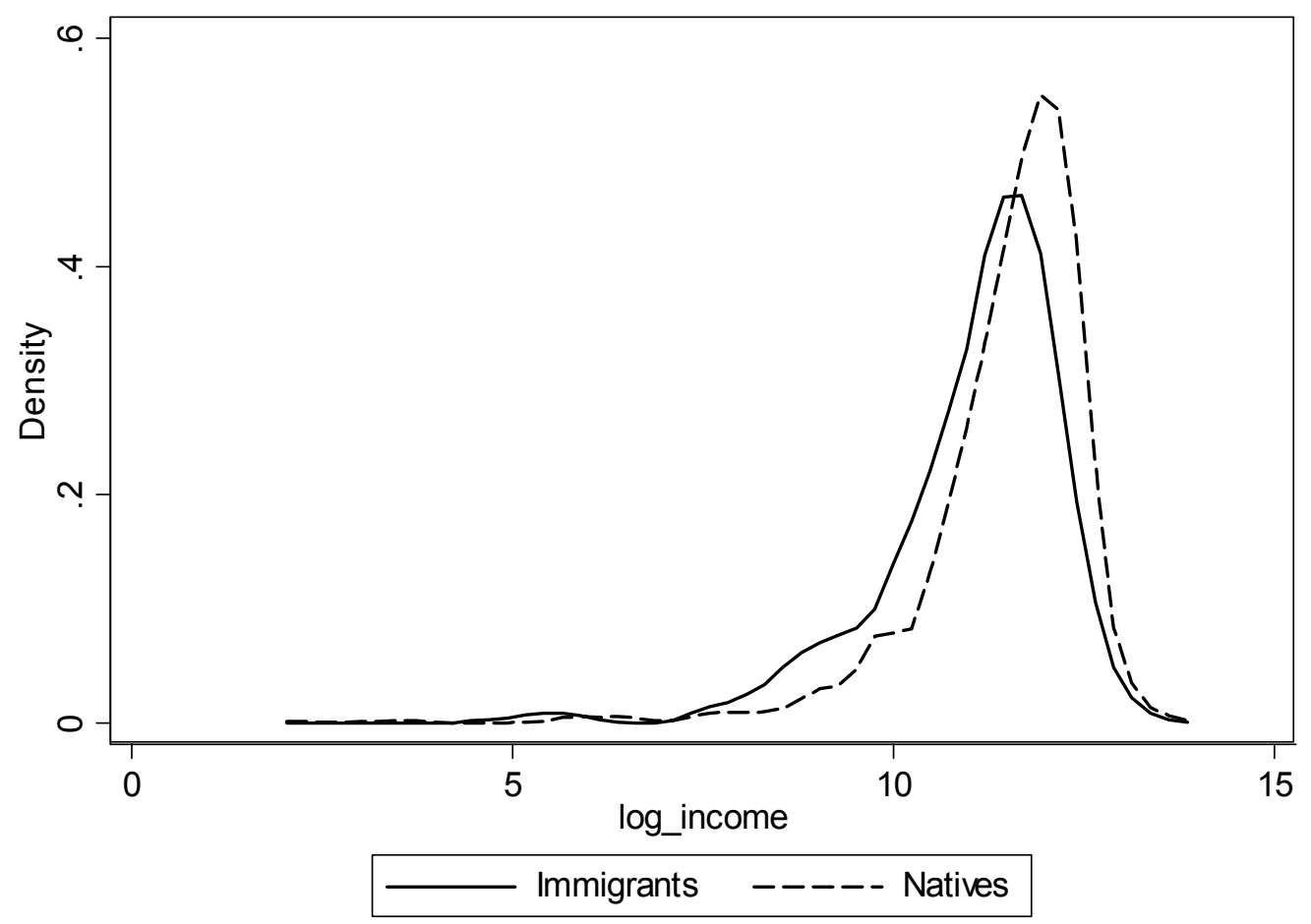

Before we look at the results of the income regressions, let us summarize what we know so far. Self-employed in Denmark and Sweden appear to be quite similar regarding the covariates that are included, with the exception for the number of years spent in the host country for Western immigrants. So far, even the immigrant/native income gap for selfemployed are similar in the countries where immigrants have lower annual incomes than natives, and the ratio is lower for non-Western immigrants.

First we show results from standard Mincer equations, estimated with ordinary least squares. The full set of covariates is included. In the quantile regressions we specify three equations where different sets of covariates are included. Only the coefficients for immigration status are presented but in the rightmost column the covariates are listed. The regressions are estimated for five percentiles and the results from the corresponding OLS are given as a comparison. The results for the two countries share a common feature in that the coefficients for non-Western immigrants who have lived in the host country for five years or more are the ones that to the largest extent are significantly different from zero. This is an important group when analysing the immigrant-native income gap as the non-Western immigrants are selfemployed more often than natives.

The interpretation and analysis of the quantile regression results is made in three steps: First we look at the differences between percentiles; secondly we look at differences in the same percentile when different sets of covariates are included and thirdly we compare the results 
for the two countries in more general terms. For both countries, and independent of specification, the immigrant-native income gap decreases over the distribution. However, the decrease is more pronounced for Sweden than for Denmark. In other words, the difference in annual income between non-Western immigrants and natives is largest among the 10 percent with lowest incomes and the difference is smallest among the 10 percent with the highest incomes. This is a robust result and it is interesting that the same pattern is found in both Denmark and Sweden. We will return to the interpretation of this finding later. ${ }^{10}$ As a comparison OLS regressions are estimated. The OLS-coefficient is quite similar to the coefficient in the $50^{\text {th }}$ percentile, but it underestimates the gap in the lower percentiles and overestimates it in the upper part of the distribution. This shows the importance of considering different parts of the distribution when estimating the immigrant-native income gap among self-employed.

In general, the negative income effect for non-Western immigrants who have lived in the host country for five years or more decreases as we control for more variables.

Next we look at the differences and similarities between the countries. We will again focus on non-Western immigrants who have lived in the host country for five years or more. The general pattern of more negative coefficient values in the lower end of the distribution than in the upper part of it is shared by both countries. This is an indication that the explanation for this can be found in something that the countries share, or that the immigrants coming to the two countries have similar characteristics. When we control for industry and other characteristics the coefficient is smaller in Sweden than in Denmark down to the $50^{\text {th }}$ percentile. For example, among the 10 percent who have the highest incomes, immigrants have 38 percentage points lower annual income on average in Sweden compared to 51 percentage points lower income in Denmark for the same group. Below the $50^{\text {th }}$ percentile there is a small difference between the countries. It is interesting to note that the $\mathrm{R}^{2}$ value is higher in Denmark than in Sweden, especially in the third specification. That is to say that the covariates can explain much more of the variation in the annual incomes in Denmark than what the same covariates can for Sweden.

\footnotetext{
${ }^{10}$ For Denmark, the coefficients in the $10^{\text {th }}$ and $90^{\text {th }}$ percentile for immigrants from non-western regions who have lived in Denmark for five years or more are significantly different from each other at the 10 per cent level of significance. For Sweden the corresponding coefficients are significantly different from each other at the 1 per cent level of significance. For neither country are the coefficients in the $25^{\text {th }}$ and $75^{\text {th }}$ percentiles significantly different from each other.
} 
Table 3. Coefficients estimated by OLS. Dependent variable is log annual income in 1999 from self- employment. Robust standard errors in brackets

\begin{tabular}{|c|c|c|}
\hline & DENMARK & SWEDEN \\
\hline Age & $\begin{array}{c}\mathbf{0 . 0 5} \\
{[0.014]^{* * *}}\end{array}$ & $\begin{array}{c}\mathbf{0 . 0 8} \\
{[0.19]^{* * *}}\end{array}$ \\
\hline Age squared/1000 & $\begin{array}{c}\mathbf{- 0 . 5 5} \\
{[0.163]^{* * *}}\end{array}$ & $\begin{array}{c}\mathbf{- 0 . 8 9} \\
{[0.218]^{* * *}}\end{array}$ \\
\hline Women & $\begin{array}{c}-\mathbf{0 . 3 9} \\
{[0.044]^{* * *}}\end{array}$ & $\begin{array}{c}\mathbf{- 0 . 3 6} \\
{[0.066]^{* * *}}\end{array}$ \\
\hline $\begin{array}{l}\text { One parent born in host country, } \\
\text { one in Western country }\end{array}$ & $\begin{array}{c}-\mathbf{0 . 2 5} \\
{[0.159]}\end{array}$ & $\begin{array}{c}\mathbf{- 0 . 0 9} \\
{[0.113]}\end{array}$ \\
\hline $\begin{array}{l}\text { One parent born in host country, } \\
\text { one in a non-Western country }\end{array}$ & $\begin{array}{c}\mathbf{- 0 . 1 3} \\
{[0.183]}\end{array}$ & $\begin{array}{c}\mathbf{0 . 1 3} \\
{[0.142]}\end{array}$ \\
\hline $\begin{array}{l}\text { Both parents born in a Western } \\
\text { country }\end{array}$ & (dropped) & $\begin{array}{c}\mathbf{0 . 0 0} \\
{[0.183]}\end{array}$ \\
\hline $\begin{array}{l}\text { Both parents born in a non-Western } \\
\text { country }\end{array}$ & $\begin{array}{c}\mathbf{- 0 . 4 3} \\
{[0.177]^{* *}}\end{array}$ & $\begin{array}{c}\mathbf{- 0 . 1 3} \\
{[0.202]}\end{array}$ \\
\hline $\begin{array}{l}\text { Born in a Western country; lived } \\
\text { in host country for five years or more }\end{array}$ & $\begin{array}{c}\mathbf{- 0 . 4 4} \\
{[0.194]^{* *}}\end{array}$ & $\begin{array}{l}-\mathbf{0 . 0 0} \\
{[0.090]}\end{array}$ \\
\hline $\begin{array}{l}\text { Born in a Western country; lived } \\
\text { in host country for less than five years }\end{array}$ & $\begin{array}{c}\mathbf{- 0 . 1 6} \\
{[0.255]}\end{array}$ & $\begin{array}{c}\mathbf{0 . 4 6} \\
{[0.362]}\end{array}$ \\
\hline $\begin{array}{l}\text { Born in a non-Western country; lived } \\
\text { in host country for five years or more }\end{array}$ & $\begin{array}{l}\mathbf{- 0 . 7 7} \\
{[0.108]^{* * *}}\end{array}$ & $\begin{array}{c}-\mathbf{0 . 5 5} \\
{[0.083]^{* * *}}\end{array}$ \\
\hline $\begin{array}{l}\text { Born in a non-Western country; lived } \\
\text { in host country for less than five years }\end{array}$ & $\begin{array}{c}-\mathbf{0 . 9 3} \\
{[0.199]^{* * *}}\end{array}$ & $\begin{array}{l}-1.55 \\
{[0.538]^{* * *}}\end{array}$ \\
\hline Primary school less than 9 years SE & & $\begin{array}{c}-\mathbf{- 0 . 0 6} \\
{[0.078]}\end{array}$ \\
\hline Primary school $9(10)$ years SE & & $\begin{array}{c}-\mathbf{0 . 0 1} \\
{[0.062]}\end{array}$ \\
\hline Upper secondary less than 2 years SE & & reference \\
\hline Upper secondary 2 years or more SE & & $\begin{array}{c}\mathbf{0 . 0 8} \\
{[0.063]}\end{array}$ \\
\hline Higher education less than 3 years SE & & $\begin{array}{c}\mathbf{0 . 0 7} \\
{[0.091]}\end{array}$ \\
\hline Higher education 3 years or more SE & & $\begin{array}{c}\mathbf{0 . 1 0} \\
{[0.102]}\end{array}$ \\
\hline Post graduate education SE & & $\begin{array}{c}\mathbf{- 1 . 5 9} \\
{[0.921]^{*}}\end{array}$ \\
\hline Primary school $9(10)$ years DK & $\begin{array}{c}\mathbf{- 0 . 0 4} \\
{[0.098]}\end{array}$ & \\
\hline Upper secondary school DK & reference & \\
\hline Vocational education DK & $\begin{array}{c}\mathbf{0 . 0 9} \\
{[0.095]}\end{array}$ & \\
\hline Short higher education DK & $\begin{array}{c}\mathbf{0 . 0 3} \\
{[0.124]}\end{array}$ & \\
\hline Medium-length higher education DK & $\begin{array}{c}\mathbf{0 . 1 4} \\
{[0.118]}\end{array}$ & \\
\hline Long higher education DK & $\begin{array}{c}\mathbf{0 . 3 1} \\
{[0.114]^{* * *}}\end{array}$ & \\
\hline Married & $\begin{array}{c}\mathbf{0 . 1 5} \\
{[0.042]^{* * *}}\end{array}$ & $\begin{array}{c}\mathbf{0 . 1 2} \\
{[0.047]^{* * *}}\end{array}$ \\
\hline Number of employees SE & & $\begin{array}{c}\mathbf{0 . 1 2} \\
{[0.013]^{* * *}}\end{array}$ \\
\hline $\begin{array}{l}0 \text { employees DK } \\
1-9 \text { employees DK }\end{array}$ & $\begin{array}{c}-\mathbf{- 0 . 6 0} \\
{[0.032]^{* * *}} \\
\text { reference }\end{array}$ & \\
\hline 10-49 employees DK & $\begin{array}{c}\mathbf{0 . 5 9} \\
{[0.089]^{* * *}}\end{array}$ & \\
\hline More than 50 employees DK & $\begin{array}{c}1.17 \\
{[0.377]^{* * *}}\end{array}$ & \\
\hline Industry & yes & yes \\
\hline Constant & $\begin{array}{c}\mathbf{1 1 . 7 9} \\
{[0.314]^{* * *}}\end{array}$ & $\begin{array}{c}\mathbf{9 . 6 7} \\
{[0.436]^{* * *}}\end{array}$ \\
\hline $\begin{array}{l}\mathrm{R}^{2} \\
\text { Number of observations }\end{array}$ & $\begin{array}{l}0.272 \\
2808\end{array}$ & $\begin{array}{l}0.142 \\
2276\end{array}$ \\
\hline
\end{tabular}




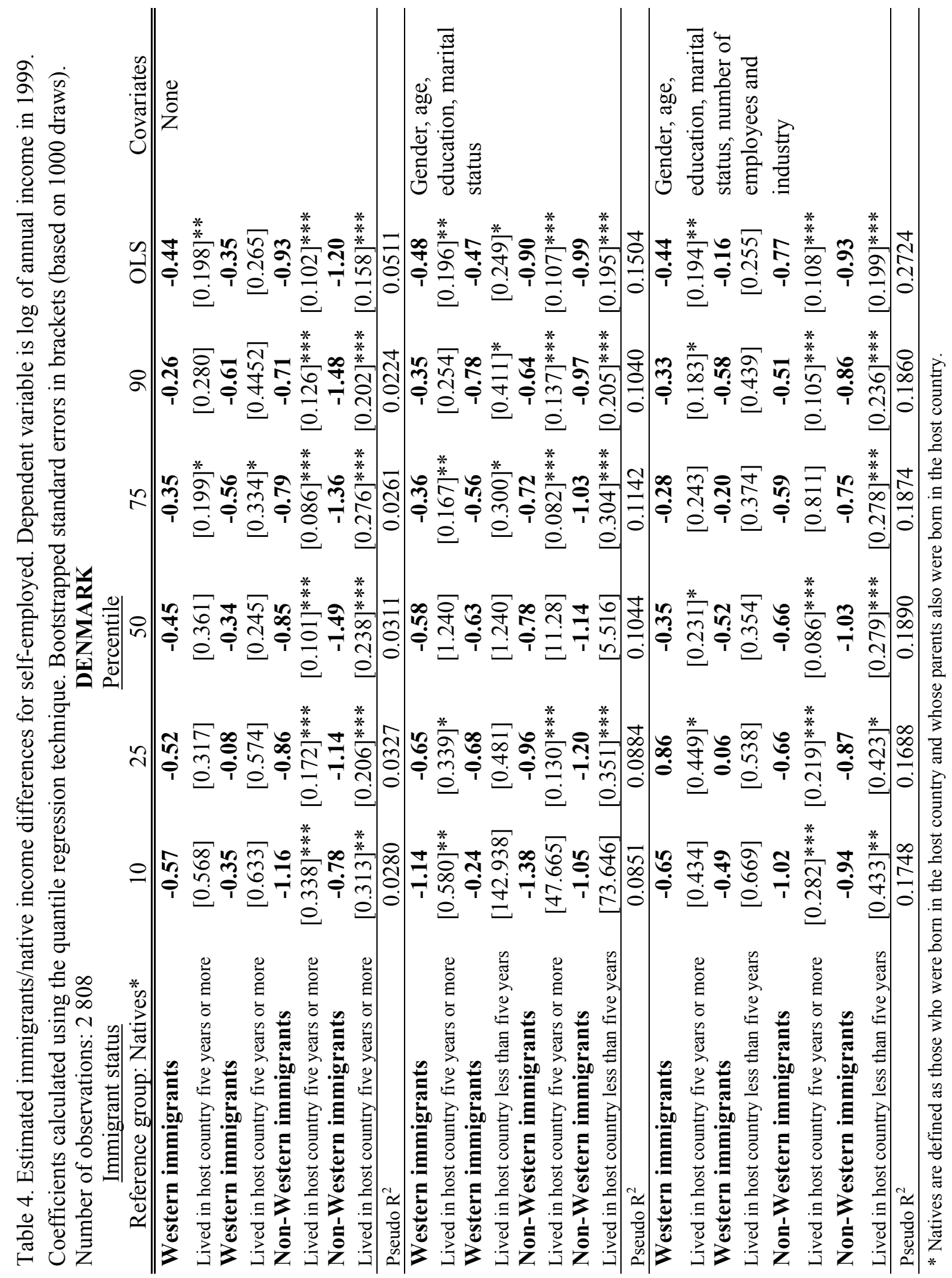




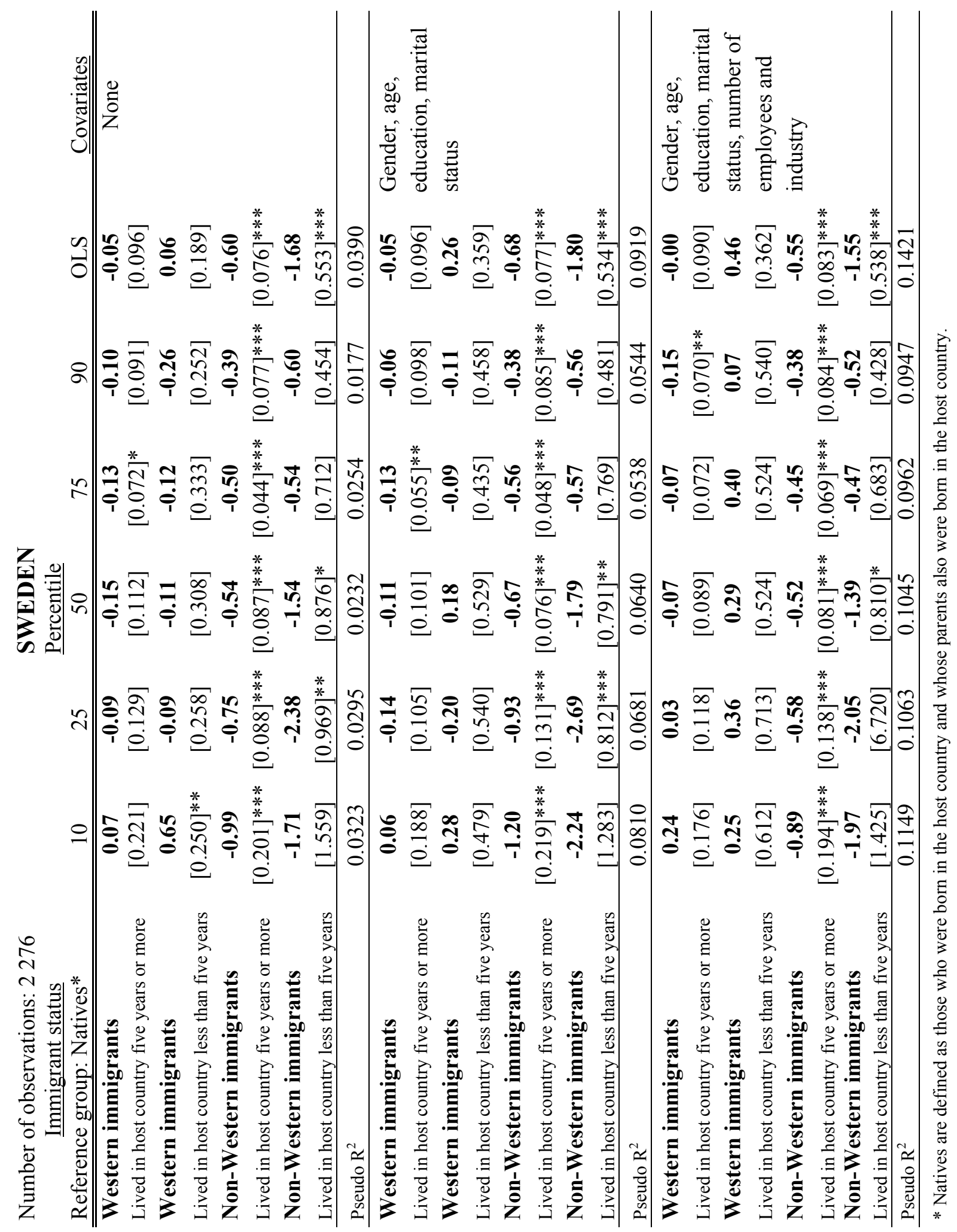


To further explore the mechanisms behind differences in the estimated immigrant/native income gap, we estimate a new specification of the quantile regressions where we can better consider the impact of years spent in the host country. This can only be done for Sweden due to lack of information in the Danish data. Part of the explanation of a smaller difference in the highest percentiles than in the lowest can be that immigrants found in the upper end of the income distribution have spent more years in the host country. We then expect that by controlling for number of years spent in the host country the difference in the lower percentiles will decrease. In early studies by Chiswick on income differences between natives and immigrants, a smaller difference for those who have lived in the host country for a longer period of time is seen as evidence of assimilation of immigrants. ${ }^{11}$ This could be of special importance for the self-employed. Knowledge about the legislation and structures in the new country can be even important for succeeding in starting and running a business than for employees. ${ }^{12}$ The so-called first generation studies of the Chiswick type have been criticized, however, for interpreting the decrease in the immigrant/native income gap as evidence of assimilation. Another plausible explanation is that the immigrants who arrived 40 years ago differ in various respects from those who arrived five years ago. Seeing it this way, the income difference for the "oldest" immigration group and natives can not be seen as a predictor of how incomes will differ between newly arrived immigrants and natives 40 years from now. ${ }^{13}$ However, that more years spent in the host country are related to the immigrant/native income gap in different percentiles is an argument for including such a variable.

To incorporate these ideas we split the immigrant group consisting of non-western immigrants who have lived in Sweden for five years or more into two groups. In the first group we have those who have been in Sweden between five and 14 years, and in the second group we have those who have lived in Sweden for 15 years or more. By comparing the last panel in Table 4 with Table 5 we can see that splitting up the group in this way to some extent decreases the difference between the percentiles. This is true at least for incomes below the median. For those with annual incomes above the median value, dividing the immigration group in this way does not seem to decrease the difference between the $75^{\text {th }}$ and $90^{\text {th }}$ percentile. The nativeimmigrants income gap is smaller for those who have lived in Sweden for 15 years or more

\footnotetext{
${ }^{11}$ Chiswick (1978).

12 SOU 1999:49.

${ }^{13}$ Borjas (1994).
} 
and larger for those who have lived in the country between five and 14 years, compared to when we do not divide this group into two. This is a reasonable result.

A conclusion to be drawn from this exercise is that more years spent in the host country do not appear to be the main factor behind differences in the immigrant/native income gap between the percentiles. However, it can be seen that in all percentiles, self-employed immigrants who have lived in Sweden for 15 years or more have annual incomes closer to their native counterparts than what is the case for those who have lived in Sweden between five and 14 years. This result can be related to the theory of assimilation.

In section two we mentioned that it is possible that the reservation income for starting a firm is lower for immigrants than for natives, but we also argued that it is possible that immigrants differ with respect to time spent in the host country before starting a firm. We have no information in the data on when the self-employed started their business so we cannot set this in relation to arrival time for immigrants. The difference in the immigrant-native income gap between the percentiles can possibly be explained by that those in the highest percentile have spent more years in the host country before starting their firm.

A third explanation for the difference between the percentiles is also related to reservation wage and we discuss the impact of the value of the outside option when choosing to become self-employed. If self-employed immigrants in the top of the income distribution also would have had a job and would have been in the upper tail of the distribution as wage-earners then it is likely that they require a high expected profit from self-employment to choose this alternative. If the outside option of those in the lower tail of the distribution is unemployment or a low wage job, then they perhaps do not require a high expected profit to start a firm.

These explanations indicate that there may be a selection of immigrants into different parts of the income distribution. Whether this is due to differences in the length of stay in the host country, differences in the time since starting a business, the value of the outside option, language skills or something else, this paper has not been able to clarify. It is a challenge of future research to consider this selection into self-employment in more detail. 


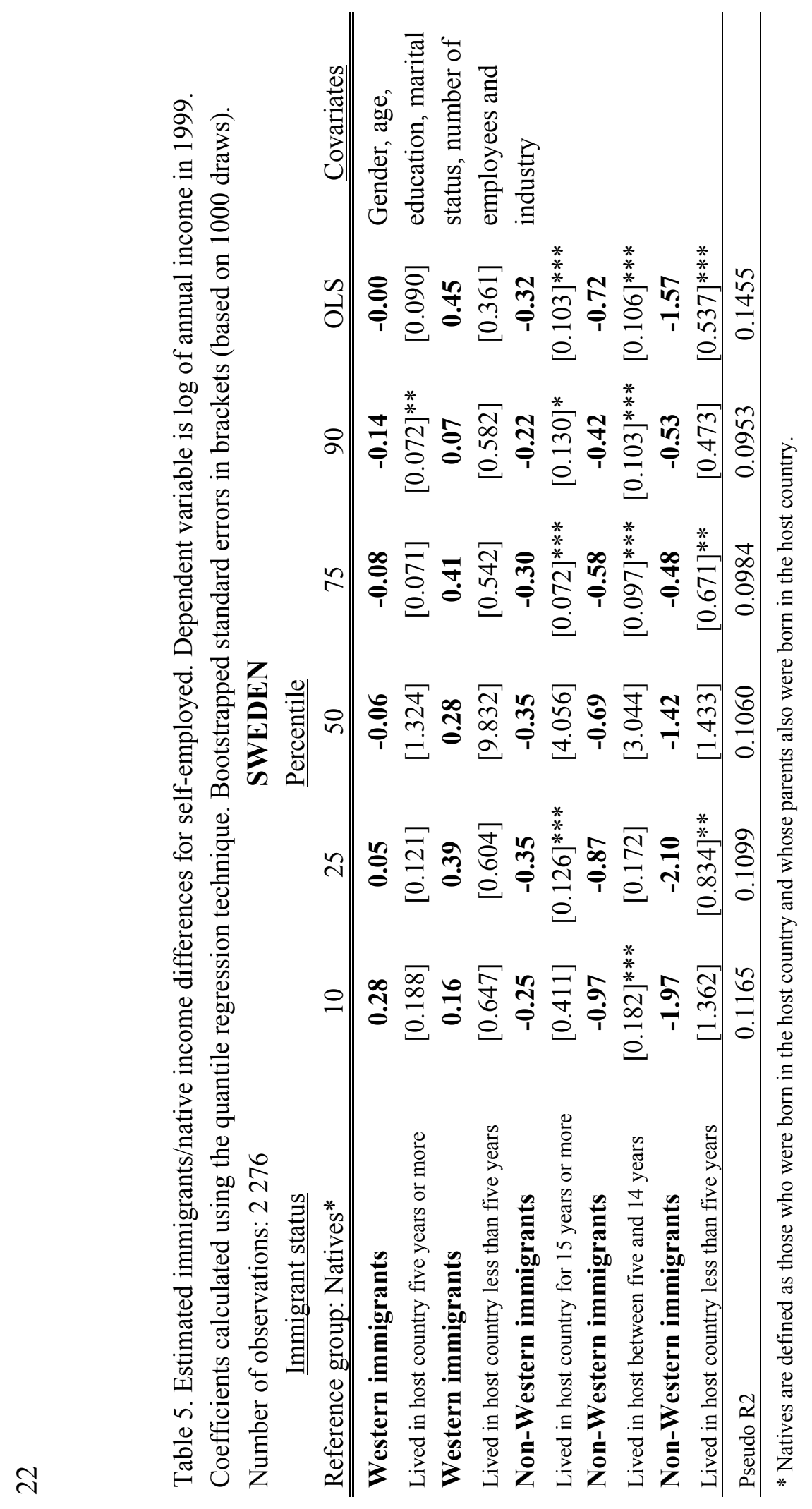


The results in generally confirm the two hypotheses.

1. Self-employed immigrants have lower incomes than self-employed natives in both countries.

2. The incomes of self-employment relative to the income of wage earners will be higher in Denmark than in Sweden.

One result we have not explained is why the non-Western immigrant/native income ratio for self-employed is higher in Sweden than in Denmark.

\section{Conclusions and summary}

In this paper we have looked at the immigrant/native income gap for self-employed. To be able to better understand the situation for self-employed in general and self-employed immigrants in particular is important for three reasons. First, this group has often been excluded from the analysis of income distributions and inequality within a society. Second, to be self-employed during some period of life has become more and more common during the last decade, but self-employment is not equally common in all groups. One knows from earlier studies from different countries that immigrants often are overrepresented in this group. Thirdly, it is often said that new smaller firms can make a major contribution to the economic growth in a country. These features make it important to understand and analyse the economic situation for self-employed and possible differences between different groups.

We have presented some new results. First, we can conclude that there is a persistent immigrant/native income gap over the entire income distribution for self-employed. Secondly, we have found that the immigrant/native income gap differs depending on where in the income distribution we look. We find a smaller gap in the $90^{\text {th }}$ percentile than in the $10^{\text {th }}$. This difference may be explained by that the immigrants make the choice to become self-employed more often than natives due to that they have problems in getting a job. If considering years spent in the host country in more detail (this was only done for Sweden), the difference diminishes in all parts of the distribution, but the pattern is still the same. Thirdly, we find the same pattern both in Denmark and Sweden. This finding suggests that self-employed immigrants from non-Western countries face about the same situation relative to self- 
employed natives in the two countries. Fourthly, the incomes of self-employed compared to those of wage-earners are higher in Denmark than in Sweden.

We have presented several possible explanations, both for the immigrant-native income gap in general and the difference in the gap between the percentiles. Due to restrictions imposed by the data we have not been able to test these explanations but since this is a rather unexplored research area, descriptive studies are needed. Hopefully future research on the immigrant-native income gap will provide us with evidence for why self-employed immigrants in Denmark and Sweden have such low incomes compared to their native counterparts.

\section{References}

Andersson, Pernilla \& Eskil Wadensjö (2004), “Other forms of employment: temporary employment agencies and self-employment”, IZA discussion paper no. 1166.

Andersson, Pernilla \& Eskil Wadensjö (2004a), "Self-employment for immigrants in Denmark and Sweden: A way to economic self-reliance?”, IZA discussion paper no. 1130.

Borjas, George J. (1994), “The Economics of Immigration”, Journal of Economic Literature, Vol. 32, pp. 1667-1717.

Bradbury, Bruce (1996), “Are the low income self-employed poor?”, SPRC Discussion Paper No. 73, December.

Brownstone, David \& Robert Valetta (2001), "The Bootstrap and Multiple Imputations: Harnessing Increased Computing Power for Improved Statistical Tests", Journal of Economic Perspectives, Vol.15, no. 4, pp. 129-141.

Chiswick, Barry R. (1978), "The Effect of Americanization on the Earnings of Foreign-Born Men”, Journal of Political Economy, Vol. 86, October, pp. 897-922.

Mooney, Christopher Z. \& Robert D. Duval (1993), Bootstrapping: A Nonparametric Approach to Statistical Inference. Sage University Paper Series on Quantitative Applications in the Social Science, Series no. 07-095. Newbury Park, CA: Sage.

Ministry of Economic Affairs (2000), The Law Model. Copenhagen: Ministry of Economic Affairs.

SOU 1999:49, Invandrare som företagare: för lika möjligheter och ökad tillväxt.

STATA-manual.

Statistics Sweden (1999). Registerbaserad arbetsmarknadsstatistik.

Vilhelmsson, Roger (2002), Wages and Unemployment of Immigrants and Natives in Sweden, Swedish Institute for Social Research, Stockholm University, Dissertation series no. 56.

Wooldridge Jeffrey M. (2002), Econometric analysis of cross section and panel data. Cambridge, Mass.: The MIT Press. 